\title{
Numerical Taxonomy of Erwinia Species Using API Systems
}

\author{
By J. MERGAERT, ${ }^{1}$ L. VERDONCK, ${ }^{1}$ K. KERSTERS, ${ }^{1}$ J. SWINGS, ${ }^{1}$ * \\ J.-M. BOEUFGRAS ${ }^{2}$ AND J. DE LEY ${ }^{1}$ \\ ${ }^{1}$ Laboratorium voor Microbiologie en microbiële Genetica, Rijksuniversiteit, \\ $K$. L. Ledeganckstraat 35, B-9000 Gent, Belgium \\ ${ }^{2}$ Laboratoire de Recherche API, La Balme-les-Grottes, F-38390, Montalieu-Vercieu, France
}

(Received 9 February 1984; revised 19 April 1984)

\begin{abstract}
API 20E, API ZYM and eight other enzymic API systems were tested on 123 strains belonging to 18 Erwinia species, six Enterobacter agglomerans strains and 22 reference strains belonging to other phytopathogenic genera and other enterobacterial species. The data obtained, from a total of 130 tests, were subjected to numerical analysis. Test reproducibility within the API 20E system varied from 88 to $100 \%$. The numerical analysis revealed 12 phenons; in six of these phenons two or three subphenons could be differentiated. Several of these (sub)phenons corresponded to established Erwinia species and could be differentiated from each other by 25 characters. No clearcut distinction could be made between the 'amylovora', 'carotovora' and 'herbicola' groups. Seven phenons were further analysed with the API 50CHE system. The results provided evidence for the retention of Er. quercina, Er. nigrifluens, Er. salicis, Er. amylovora, Er. rubrifaciens, Er. mallotivora, Er. stewartii, Er. cypripedii and Er. chrysanthemi as separate taxa and supported the synonymy within the pairs Er. ananas and Er. uredovora, Er. dissolvens and Enterobacter cloacae, Er. carotovora subsp. atroseptica and Er. carotovora subsp. carotovora, Er. milletiae and one of the Er. herbicola clusters. The inadequacy of the present classification of several Erwinia species, such as Er. herbicola and Er. rhapontici, is highlighted. The results show that API systems are a useful and rapid alternative to conventional phenotypical testing for the classification and identification of Erwinia species.
\end{abstract}

\section{INTRODUCTION}

During the last decade miniaturized biochemical procedures have been developed for the rapid identification of clinical Enterobacteriaceae and are now commercially available. One of these, API 20E (API Systems SA, Montalieu-Vercieu, France) contains 23 standardized biochemical tests and has been successfully tested in many clinical bacteriological laboratories (Butler et al., 1975; Blazevic et al., 1976; Rutherford et al., 1977; Holmes et al., 1977, 1978; Aldridge et al., 1978; Murray, 1978; Blackall, 1980; Devenish \& Barnum, 1980; Freeman et al., 1981). Non-clinical isolates of Erwinia herbicola have already been characterized using the API 20E system (Neilson \& Sparell, 1976; van Vuuren et al., 1978; De Smedt \& De Ley, 1979; De Vos et al., 1980; Ingledew et al., 1980; Haahtela et al., 1981). A standardized microsystem for the semiquantitative assay of 19 different enzymes (API ZYM) has been described by Monget (1978) and applied to the identification of many bacteria (Humble et al., 1977; Tharagonnet $e t$ al., 1977; Kilian, 1978; Frank \& Gerber, 1981; Mutimer \& Woolcock, 1982) and has also been used in taxonomic studies (Gauthier, 1976; Guillermet, 1980; O'Donnell et al., 1980; Holmes et al., 1981, 1982). Another commercially available system, API 50CHE (i.e. the API 50CH gallery used with the API 50CHE medium), is suitable for the detection of acid production from 49 carbohydrates. A similar system, API 50E, has been used for the classification and identification of various bacteria (Imbs, 1974; Ljungh et al., 1977; De Smedt \& De Ley, 1979; Logan et al., 1979; Schwan et al., 1979; De Vos et al., 1980; O’Donnell et al., 1980). 
The genus Erwinia includes organisms causing important diseases of plants; others constitute a significant fraction of the nonphytopathogenic epiphytic flora of plant surfaces and some strains are opportunistic pathogens of man and animals. Dye $(1968,1969 a, b, c)$ subdivided the genus into four so-called 'natural groups'. Strains of the 'amylovora' group (Dye, 1968), cause dry necrotic or wilt diseases on plants and include Er. amylovora, Er. salicis, Er. rubrifaciens, Er. tracheiphila, Er. nigrifluens, Er. quercina, and Er. mallotivora [assigned to the 'amylovora' group by Goto (1976)]. The 'carotovora' group (Dye, 1969a), consists of Erwinia species with strong pectolytic capacities, causing soft rots in a wide variety of plants. This group includes $E r$. carotovora, Er. chrysanthemi, Er. rhapontici and Er. cypripedii. Some authors assign the 'carotovora' group to the genus Pectobacterium (Waldee, 1945; Brenner et al., 1973). The 'herbicola' group (Dye, $1969 \mathrm{~b}$ ) consists of erwinias that (usually) produce a yellow pigment; it includes epiphytes (Er. herbicola), some phytopathogens (Er. ananas, Er. uredovora, Er. milletiae and Er. stewartii) and yellow-pigmented and related nonpigmented clinical isolates, often named Enterobacter agglomerans (Ewing \& Fife, 1972). Dye's fourth group (Dye, 1969c) contains 'atypical' erwinias, such as Er. dissolvens.

Many rearrangements have been proposed for the genus Erwinia (Brenner et al., 1972; Gardner \& Kado, 1972; Starr \& Chatterjee, 1972; Murata \& Starr, 1974; Sakazaki et al., 1976; Young et al., 1978; Dye, 1981) but a consensus has not yet been reached. The taxonomic uncertainty is illustrated by the inclusion of 21 Erwinia species as well as their synonyms (i.e. Pectobacterium, Enterobacter agglomerans) in the Approved Lists of Bacterial Names (Skerman et al., 1980). The assignment of an Erwinia culture to one of Dye's major groups (Dye, 1968, $1969 a, b)$ is largely made on the basis of pectolytic capacity (soft-rot erwinias), yellow pigmentation ('herbicola' group) and the lack of these traits in the white, non-pectolytic, wiltcausing 'amylovora' group (Starr, 1981). However, Er. rhapontici and Er. cypripedii both belong to the "carotovora' group but do not degrade pectate (Lelliott, 1974) and only $70 \%$ of the strains from the 'Er. herbicola-En. agglomerans complex' are yellow pigmented (Ewing \& Fife, 1972). Identification at the species level is problematical, unless it is based on a known phytopathogenic capacity (Starr, 1981).

This paper presents the results of an extensive biochemical and enzymic characterization of 123 Erwinia strains, 6 En. agglomerans strains and 22 reference strains using API 20E and enzymic API systems (API ZYM, OSIDASES, ESTERASES, AMINOPEPTIDASES). These results were submitted to a numerical analysis. The production of acid from carbohydrates was investigated with the API 50CHE system for 89 of these strains. Our aims were (i) to study the physiological and biochemical diversity within the genus Erwinia, (ii) to compare the groupings obtained from the numerical analysis with the current classification of Erwinia species and (iii) to investigate the applicability of various API systems for the rapid identification of members of the genus Erwinia and allied species.

\section{METHODS}

Strains investigated. Strains used in this study (Table 1) included the type strains of all Erwinia species, 22 reference strains belonging to other phytopathogenic genera and other enterobacterial species and 6 Enterobacter agglomerans strains.

API systems. The commercially available API 20E and API 50CHE systems and nine enzymic API strips were used. The commercially available API ZYM and the experimental API galleries OSIDASES, ESTERASES, AMINOPEPTIDASES AP1, AP2, AP3, AP4, AP5 and AP6 encompass 107 enzymic test substrates (Table 2), and enable the assay of 61 aminopeptidases (arylamidases), 28 glycosidases, 13 esterases, 2 phosphatases, 2 proteinases and 1 phosphoamidase.

For API 20E tests, strains were grown on nutrient agar (Oxoid) slants at $28^{\circ} \mathrm{C}$ for $24 \mathrm{~h}$. Harvested cells were suspended in $5 \mathrm{ml}$ sterile distilled water at a density of approximately $10^{8}$ cells $\mathrm{ml}^{-1}$ (McFarland no. 1) as recommended by Murray (1978). The API 20E test strips were then handled as described by the manufacturer. The galleries were incubated at $30^{\circ} \mathrm{C}$, as most Erwinia strains are not able to grow at $37^{\circ} \mathrm{C}$.

For API 50CHE tests, strains were grown on nutrient agar slants at $28{ }^{\circ} \mathrm{C}$ for $24 \mathrm{~h}$. Preparations of suspensions and inoculation were carried out as described by the manufacturer. Positive reactions after $3,6,24$ and $48 \mathrm{~h}$ incubation at $30^{\circ} \mathrm{C}$ were coded as $5,4,3$ and 2 , respectively. No acid production after $48 \mathrm{~h}$ incubation was coded as zero. 


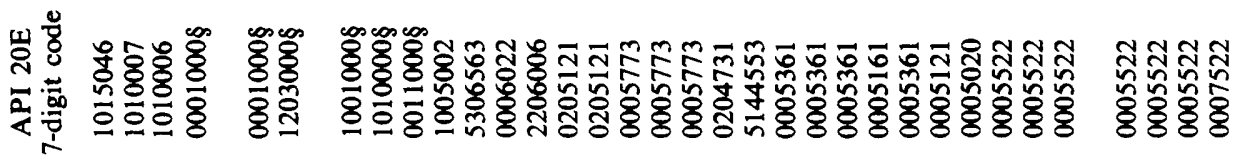

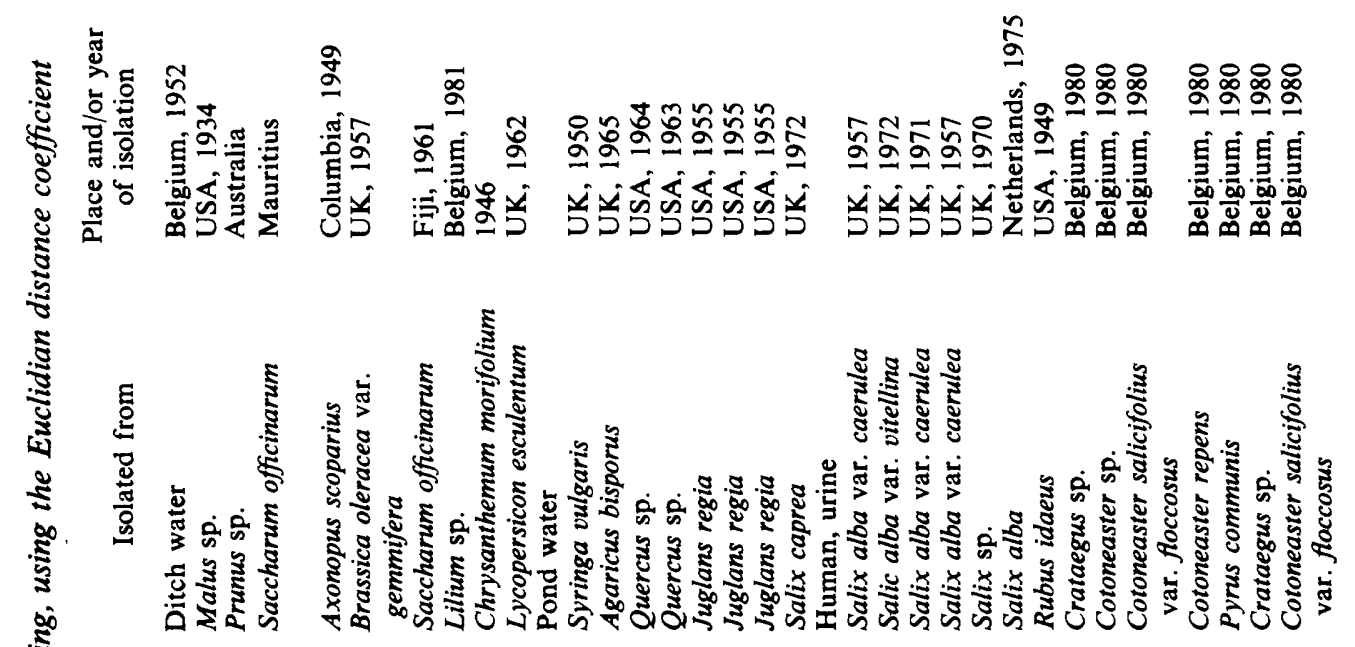

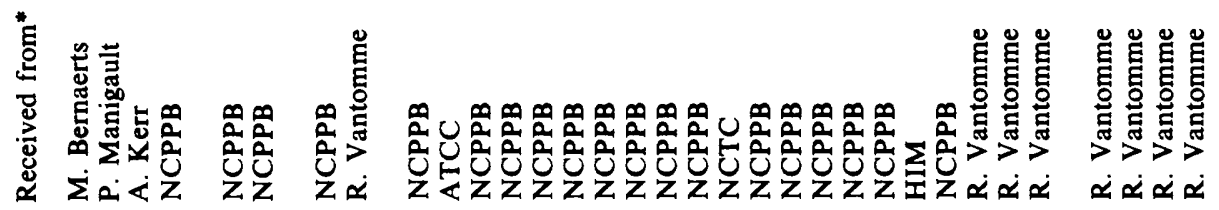

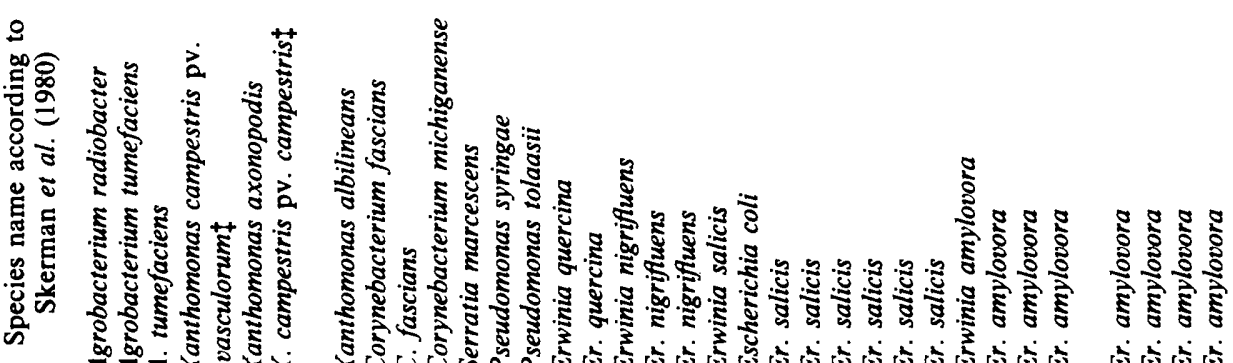

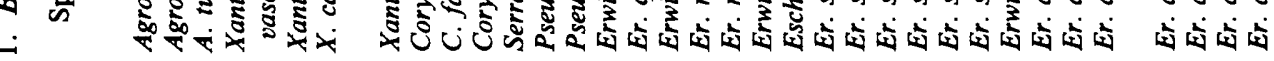

尊

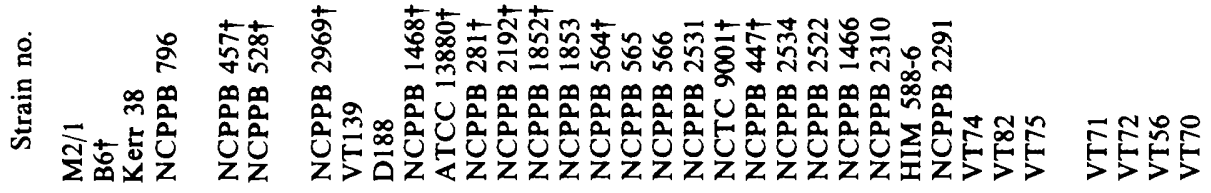

ซู ซ

空

||||||$|<\ll \infty \infty \infty|$ | 
嵌部

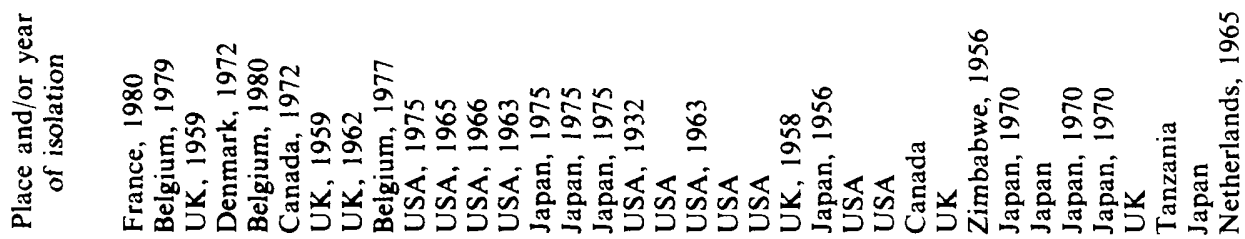

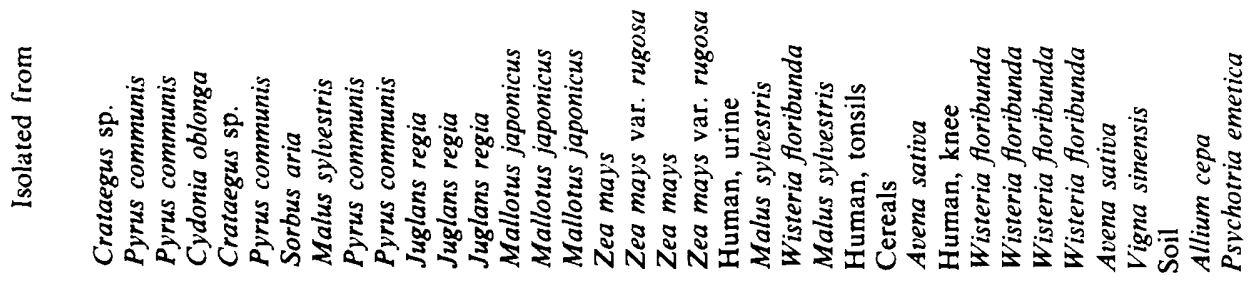

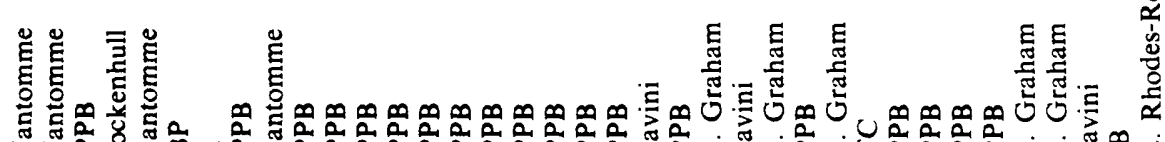

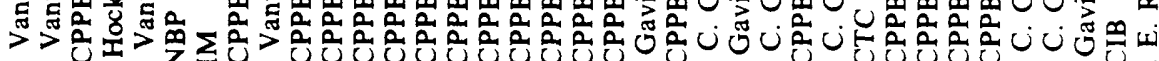

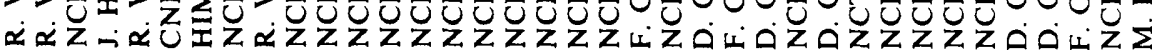

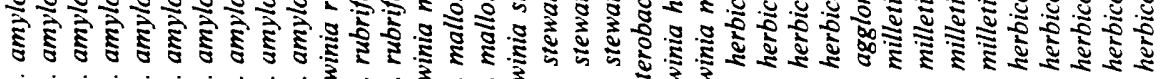

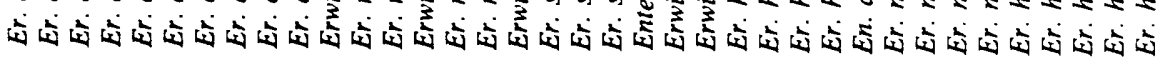

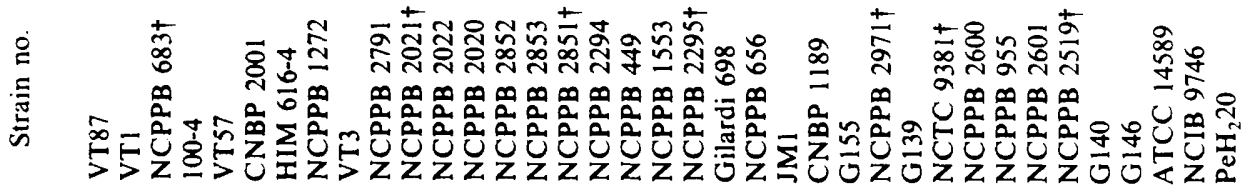

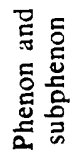

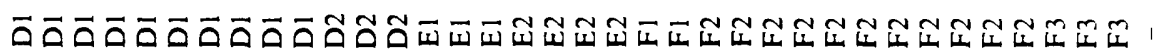




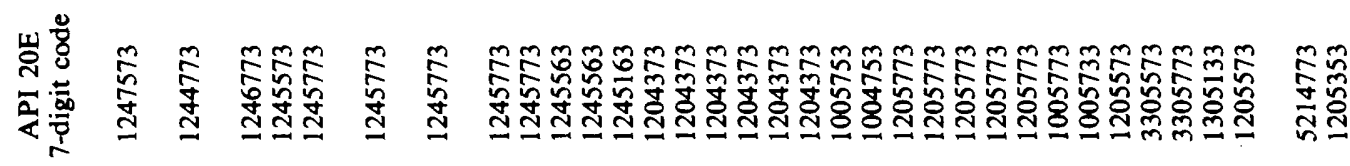

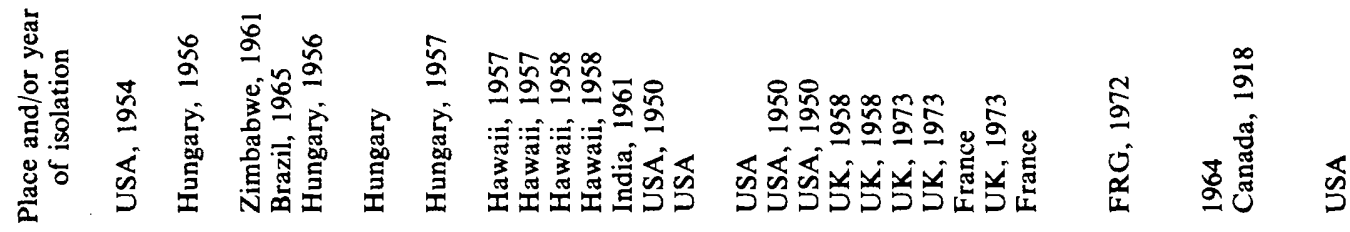

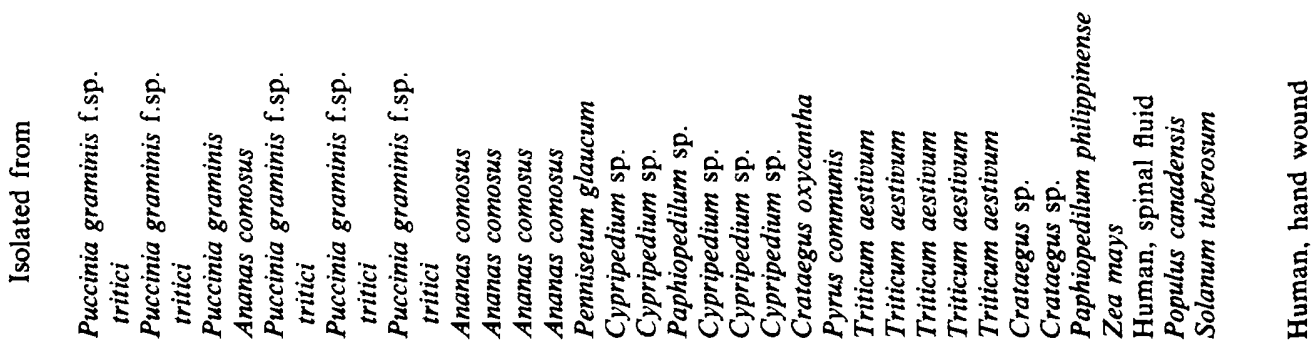

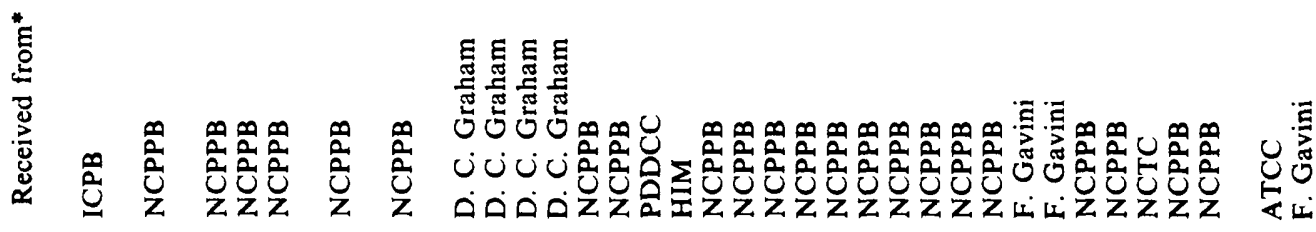

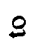

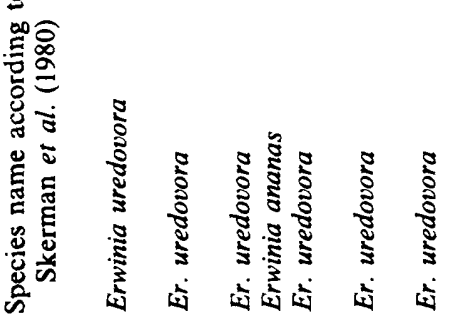

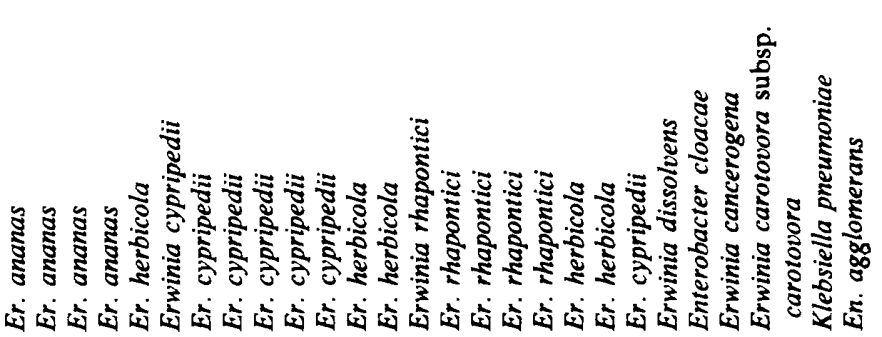

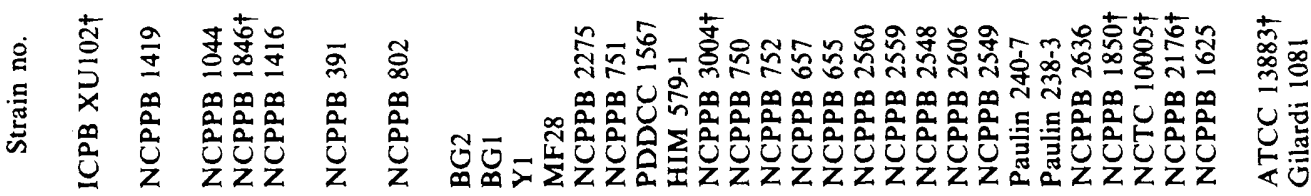

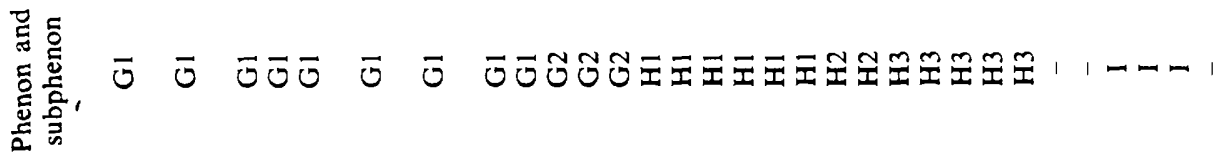




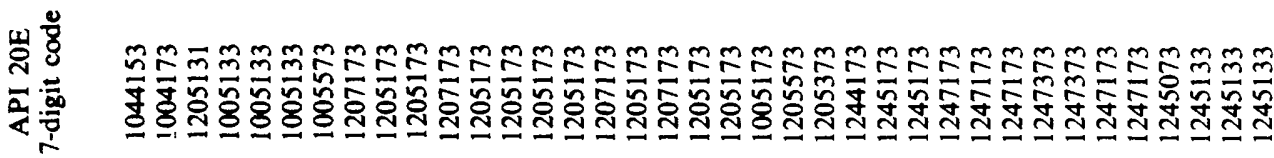

苛
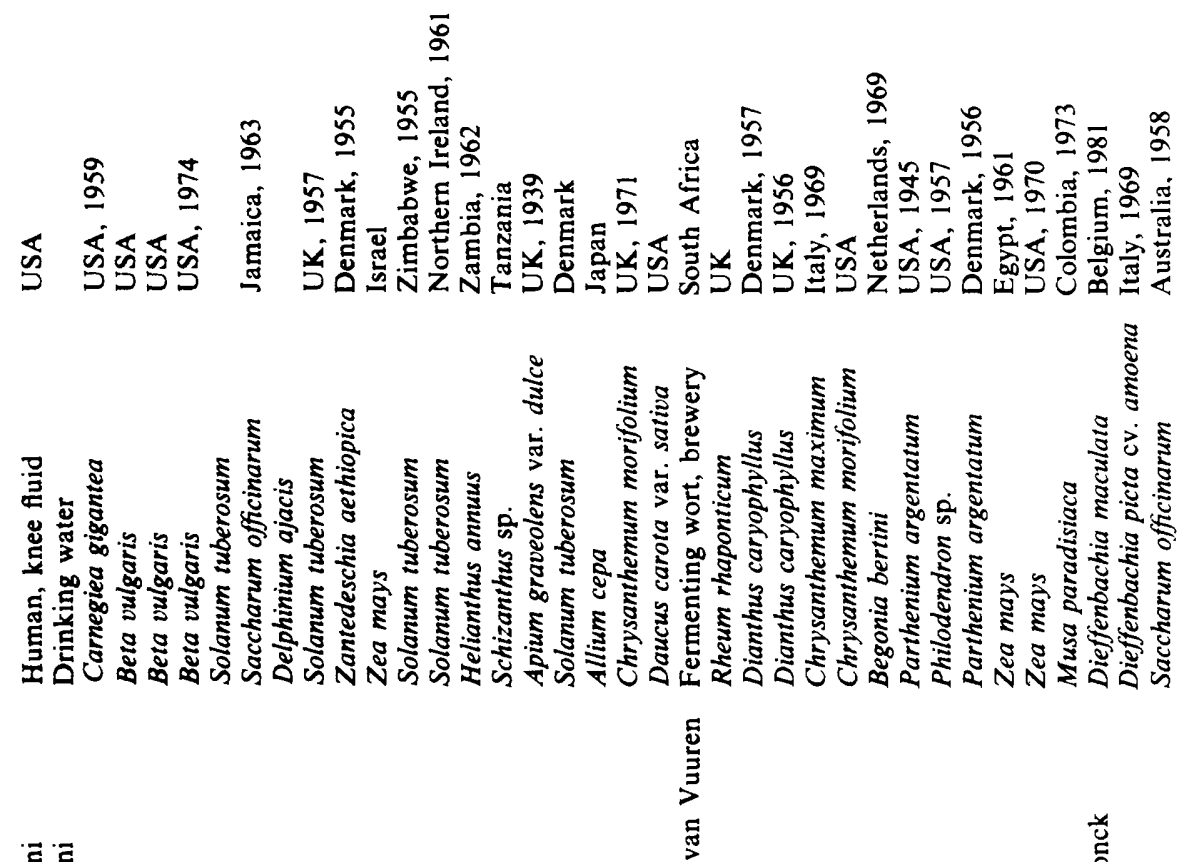

要

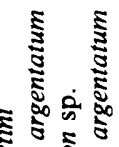

帘宅害

范

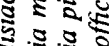

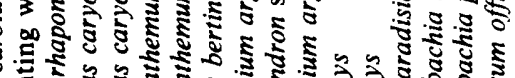

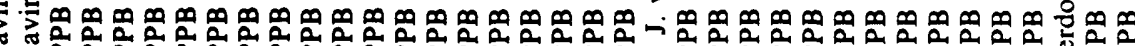

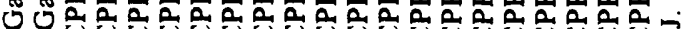
山्य

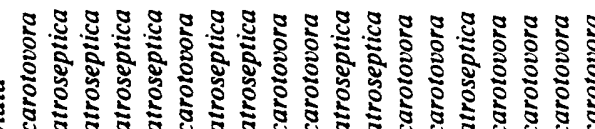

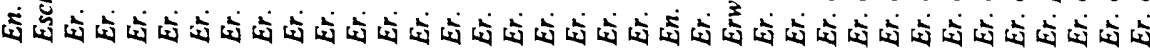

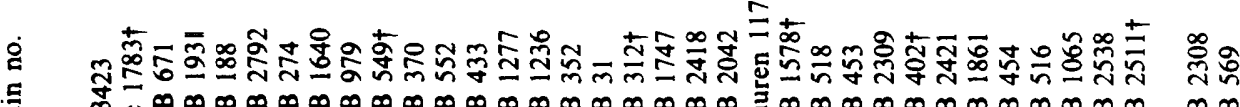

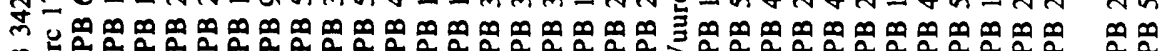

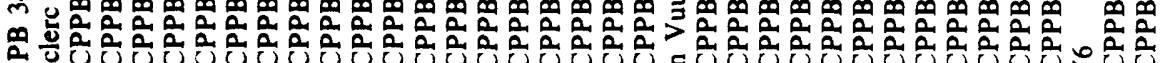

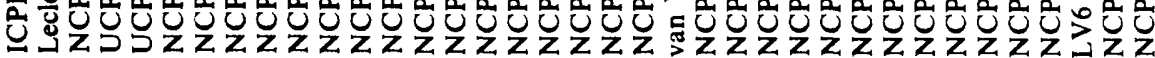




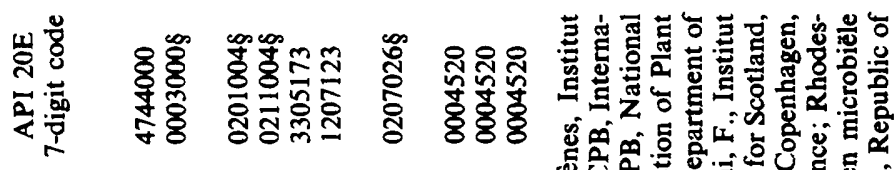

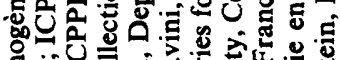

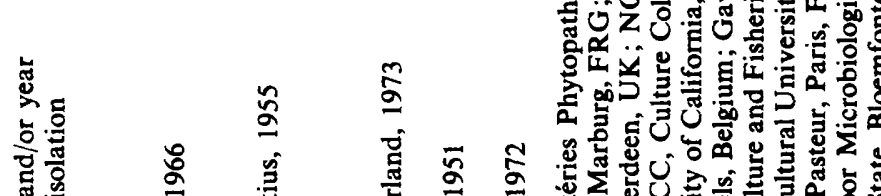

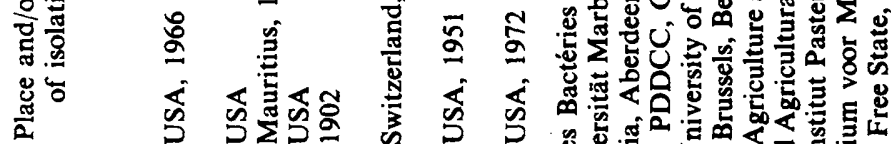

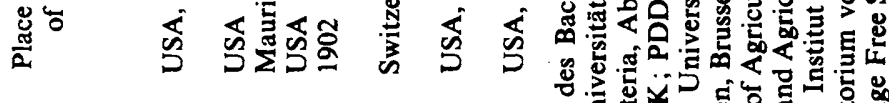

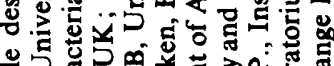

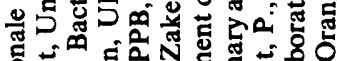

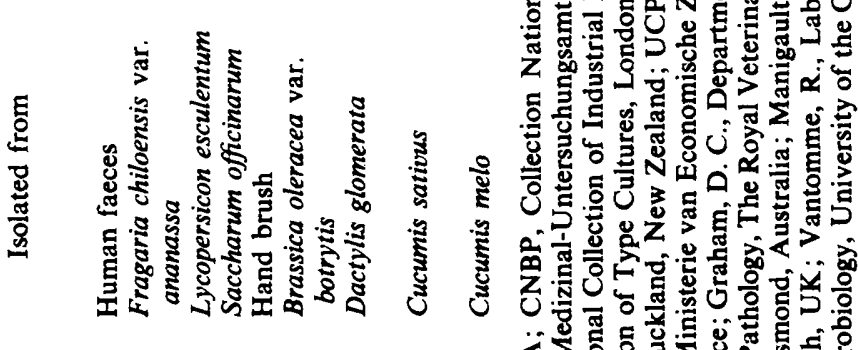

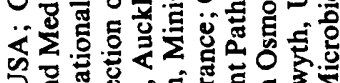

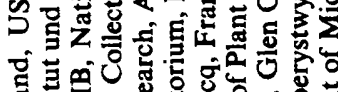

范

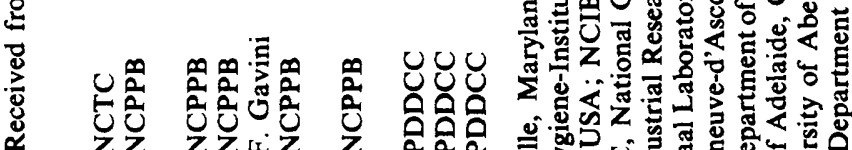

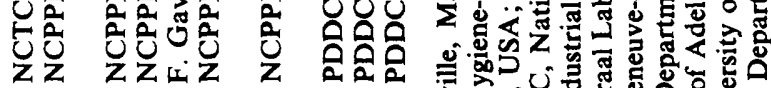

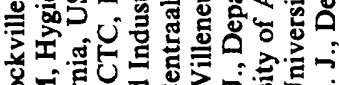

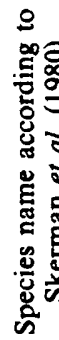

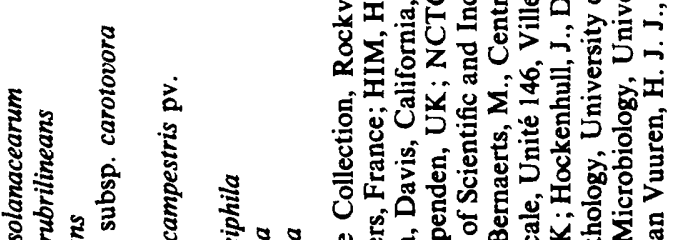

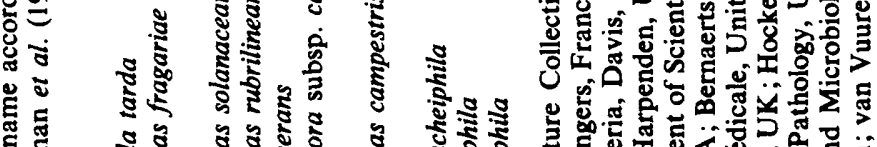

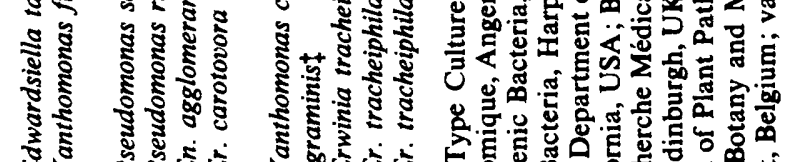

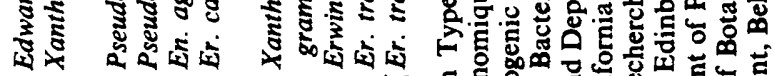
$\checkmark$ ह

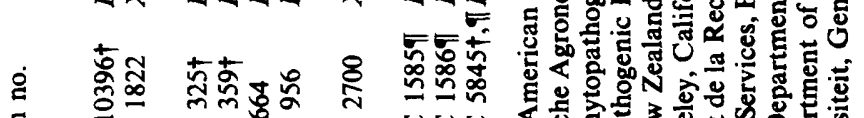

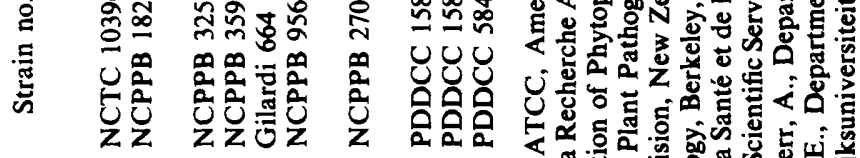

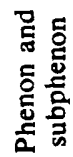


For the enzymic API tests, strains were grown in Roux flasks containing approximately $120 \mathrm{ml}$ nutrient agar and incubated at $28^{\circ} \mathrm{C}$ for $24 \mathrm{~h}$. Cells were washed off the agar surface with sterile distilled water, harvested by centrifugation ( $15 \mathrm{~min}$ at 12000 r.p.m. and $4^{\circ} \mathrm{C}$ in a Sorvall RC $2 B$ centrifuge, type SS34 rotor), and washed with $20 \mathrm{ml}$ sterile distilled water. The pellet was resuspended in approximately $1 \mathrm{ml}$ sterile distilled water and from this dense suspension two dilutions, each containing approximately $1.8 \times 10^{9} \mathrm{cells} \mathrm{ml}^{-1}$ (McFarland no. 6), were prepared: (i) in $2 \mathrm{ml}$ of normal saline and (ii) in $10 \mathrm{ml}$ of a $0.01 \mathrm{M}$-phosphate buffer $\mathrm{pH}$. The test strips were placed in their moistened plastic incubation trays and inoculation was carried out as follows: two drops of suspension (i) were added to each cupule of the API ZYM strip, and two drops of suspension (ii) were added to the cupules of the OSIDASES, ESTERASES and AMINOPEPTIDASES AP1 to AP6 strips. All the enzymic galleries were incubated at $30^{\circ} \mathrm{C}$ for $4 \mathrm{~h}$. One drop of a $0 \cdot 1 \mathrm{M}-\mathrm{NaOH}$ solution was then added to each cupule of the OSIDASES strips and positive reactions (denoted by the appearance of a yellow colour) were recorded immediately. One drop of reagent A [containing $10 \%(\mathrm{w} / \mathrm{v}) \mathrm{SDS}$ in a $2 \mathrm{M}$-Tris/HCl buffer $\mathrm{pH} 7.6$ to 7.8 ] and one drop of reagent B [containing 0.3\% (w/v) Fast Blue B in 2-methoxyethanol] were added to each cupule of the other test strips, which were then exposed to a $600 \mathrm{~W}$ light source for $5 \mathrm{~min}$ to destroy excess reagent B. Positive reactions were denoted by a colour change. The results were graded 0 to 5 by comparison with the colour chart provided by the manufacturer. Codes $0,1,2,3,4$ and 5 correspond to approximately $0,5,10,20,30$ and over $40 \mathrm{nM}$, respectively, of hydrolysed substrate.

Data analysis. Numerical analysis was carried out on the data obtained from all strains (except for Er. tracheiphila; see below) listed in Table 1 with API 20E, API ZYM, OSIDASES, ESTERASES and AMINOPEPTIDASES AP1 to AP6 systems. The results obtained in the API ZYM, ESTERASES and AMINOPEPTIDASES AP1 to AP6 systems were coded as semiquantitative characters using the original record scores of 0 (negative), 1, 2, 3, 4 and 5 (weakly to strongly positive). The mean value of the positive reactions obtained in these systems was approximately 3 for this data set. Consequently, the results of the API 20E and OSIDASES tests were coded 3 (positive), 1 (weakly positive) and 0 (negative). The Euclidian distance and Canberra metric coefficients were used to compute dissimilarities and clustering was achieved by the unweighted average pair group method (UPGMA) (Sneath \& Sokal, 1973) using the CLUSTAN program (Wishart, 1978) on the Siemens 7541 (BS 2000) computer of the Centraal Digitaal Rekencentrum of the Rijksuniversiteit Gent. The results of the API 20E tests were also recorded as seven-digit profile numbers as described by the manufacturer and the profiles obtained were identified using the API 20E Analytical Profile Index (1983 edition, no. 2019) and the API computer service.

\section{RESULTS AND DISCUSSION}

\section{Test reproducibility}

Seventeen strains were tested twice in the API 20E, API ZYM, OSIDASES, ESTERASES and AMINOPEPTIDASES strips. The Euclidian distance coefficients calculated between the replicates had a mean and standard deviation of $0.48 \pm 0 \cdot 19$. Five tests, the hydrolysis of 2naphthyl butyrate, L-leucyl-2-naphthylamide, 2-naphthyl- $\beta$-D-galactopyranoside, $p$-nitrophenyl- $\beta$-D-galactopyranoside-6-phosphate, and L-histidyl-L-phenylalanine-2-naphthylamide, showed considerable disagreement in more than 3 of 17 duplicated strains. Test reproducibility within the API 20E system varied from 88 to $100 \%$. Highest reproducibility was obtained for the tests contained in the API 50CHE system, where only 3 tests showed a slight disagreement in one of the 7 duplicated strains.

Numerical analyses of the data obtained from the API 20E, API ZYM, OSIDASES, ESTERASES and AMINOPEPTIDASES API to AP6 systems, applied to 151 strains

Numerical analysis, using the Euclidian distance coefficient, revealed 12 phenons at the distance level of $d=0.95$. In six of the phenons, definite subphenons could be distinguished (Fig. 1). Several of these (sub)phenons (A, B, C, D1, D2, E1, E2, H1, H3, K and L) corresponded to established Erwinia species (Table 1, Fig. 1). All Erwinia strains were separated from the nonenterobacterial strains at $d=1.83$, except for the two Er. quercina strains (phenon A) and $E r$. carotovora subsp. carotovora NCPPB 956 (unclustered). The numerical analysis using the Canberra metric coefficient gave similar results.

\section{Biochemical and enzymic characteristics of Erwinia}

The results of API 20E, API ZYM, OSIDASES, ESTERASES and AMINOPEPTIDASES AP1 to AP6 systems are listed in Table 2. 
All strains classified in phenons $F, G, H, I, J, K$ and $L$ as well as the ungrouped strains classified between phenons $F$ and $L$ in the dendrogram (Fig. 1; Table 1) were submitted to further analysis with the API 50CHE system in order to examine the discriminative potential of this system, and to trace additional tests for the differentiation of phenons and subphenons $F 1$, F2, F3, G1, G2, H1, H2, H3, I, J, K1, K2 and L. All the strains investigated with this system produced acid within $48 \mathrm{~h}$ from D-ribose, D-galactose, D-glucose, D-fructose, D-mannose, mannitol and $N$-acetylglucosamine, but not from L-xylose, $\beta$-methylxyloside or glycogen. None of the Erwinia or En. agglomerans strains studied with this system produced acid from L-sorbose, starch, D-tagatose and L-arabitol, and fewer than 5\% produced acid from erythritol, adonitol, inulin, melezitose, xylitol, D-turanose, D-lyxose and D- and L-fucose. More than $95 \%$ of these Erwinia and En. agglomerans strains produced acid from L-arabinose, L-rhamnose, arbutin and salicin. The remaining tests were positive for at least $5 \%$ and at most $95 \%$ of these Erwinia and En. agglomerans strains. The API 50CHE system provided additional differential tests for separating the subphenons and phenons F1, F2, F3, G1, G2, H1, H2, H3, I, J, K1, K2 and L (Table 3).

\section{Comments on the taxonomy of Erwinia as revealed by API systems}

It is evident from the numerical analysis (Fig. 1) that no sharp distinction can be made between the 'amylovora', 'herbicola' and 'carotovora' groups. For example Er. quercina (phenon A) and Er. nigrifluens (phenon B) are remote from each other and from the other species of the 'amylovora' group (Er. salicis, Er. amylovora, Er. rubrifaciens and Er. Mallotivora). Erwinia stewartii is phenotypically closer to the latter four species of the 'amylovora' group than to any species of the 'herbicola' group, and Er. cypripedii, considered as a member of the 'carotovora' group, is more related to some Er. herbicola strains than to Er. carotovora or Er. chrysanthemi. Both numerical analyses of phenotypic characteristics (Dye, 1981) and DNA:DNA hybridization studies (Murata \& Starr, 1974; Azad \& Kado, 1980) have failed to support these 'natural' groups. Dye (1981) compared four different clustering methods, but none provided a definite division into the three groups. Consequently these three groups have recently been abandoned (Lelliott \& Dickey, 1984).

The six species of the 'amylovora' group, (Er. quercina, Er. nigrifluens, Er. salicis, Er. amylovora, Er. rubrifaciens and Er. mallotivora) were recovered as separate (sub)phenons A, B, C, D1, D2, and E1, respectively (Fig. 1). However, it should be noted that only very few strains of Er. quercina, Er. nigrifluens, Er. rubrifaciens and Er. mallotivora were available for inclusion in our study. Erwinia tracheiphila strains were not included in the numerical analyses because they grew poorly on nutrient agar and growth on this medium was a prerequisite for the standardized testing in the enzymic API systems. Indeed, it has been stressed that a strict control of medium and growth time is necessary in order to obtain comparable enzymic profiles (Westley et al., 1967). In each of the four dendrograms presented by Dye (1981), the following species were recovered as well-separated clusters: Er. nigrifluens, Er. salicis, Er. tracheiphila and Er. amylovora. The strains of Er. quercina and Er. rubrifaciens consistently formed one phenon and segregated only at high similarity levels. Dye (1981) considered them as two pathovars of one species: Er. quercina pv. quercina and Er. quercina pv. rubrifaciens. However, our results and the data from DNA : DNA hybridizations (Brenner et al., 1974; Murata \& Starr, 1974; Azad \& Kado, 1980) showed that Er. amylovora, Er. nigrifluens, Er. salicis, Er. mallotivora, Er. tracheiphila, Er. quercina and Er. rubrifaciens each form well-separated clusters, strongly suggesting that all should be retained as separate species. The API 20E system allows an easy differentiation between them. The specific and unique seven-digit profile numbers are given for each in Table 1. Within the genus Erwinia, the hydrolysis of L-hydroxyproline-2-naphthylamide is restricted to cultures of Er. quercina. Hydrolysis of this substrate seems to occur more frequently in other enterobacterial genera, e.g. Serratia (Godsey et al., 1981).

The four strains of Er. stewartii, including the type strain NCPPB 2295, clustered together in a homogeneous subphenon E2 and showed higher similarity to members of the 'amylovora' group [Er. mallotivora (subphenon E1), Er. rubrifaciens (subphenon D2), Er. amylovora (subphenon D1) and Er. salicis (phenon C)] than to any species of the 'herbicola' group. In all four numerical 


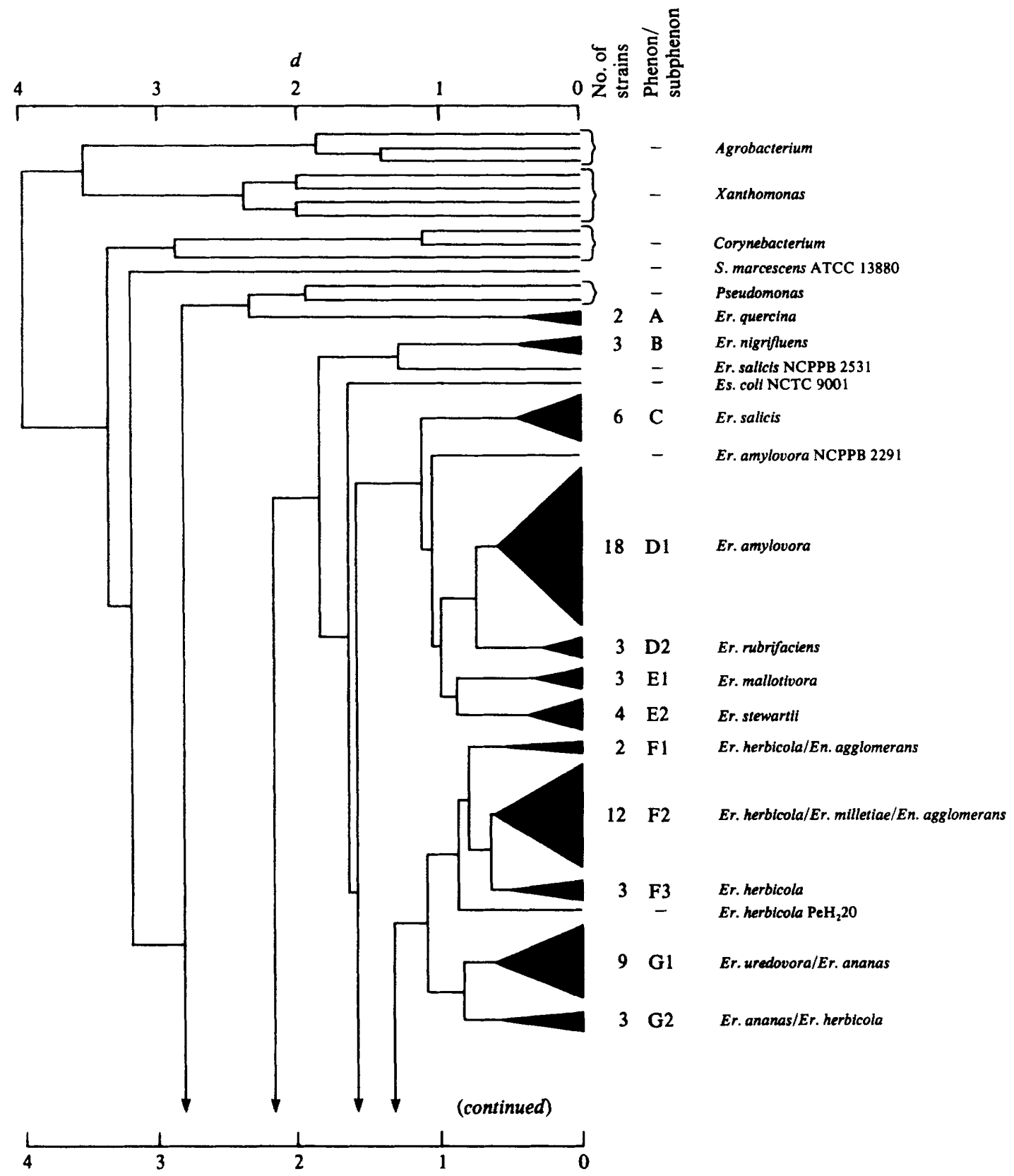

Fig. 1. Simplified dendrogram derived from the unweighted, average pair group clustering of Euclidian distance coefficients. For each of the 151 strains, 23 API 20 E and 107 enzymic tests from the API ZYM, OSIDASES, ESTERASES and AMINOPEPTIDASES systems were determined. All strains are in the same sequence as in Table 1.

analyses prepared by Dye (1981), Er. stewartii constituted a homogeneous cluster close to Er. amylovora. It is clear that the current classification of Er. stewartii in the 'herbicola' group is no longer justified. Er. stewartii formed a distinct species that could be recognized by a specific API 20E profile (Table 1).

The strains labelled Er. herbicola were heterogeneous and were recovered in five (sub)phenons (F1, F2, F3, G2 and H2 in Fig. 1). Indeed some strains formed single-member clusters. This 


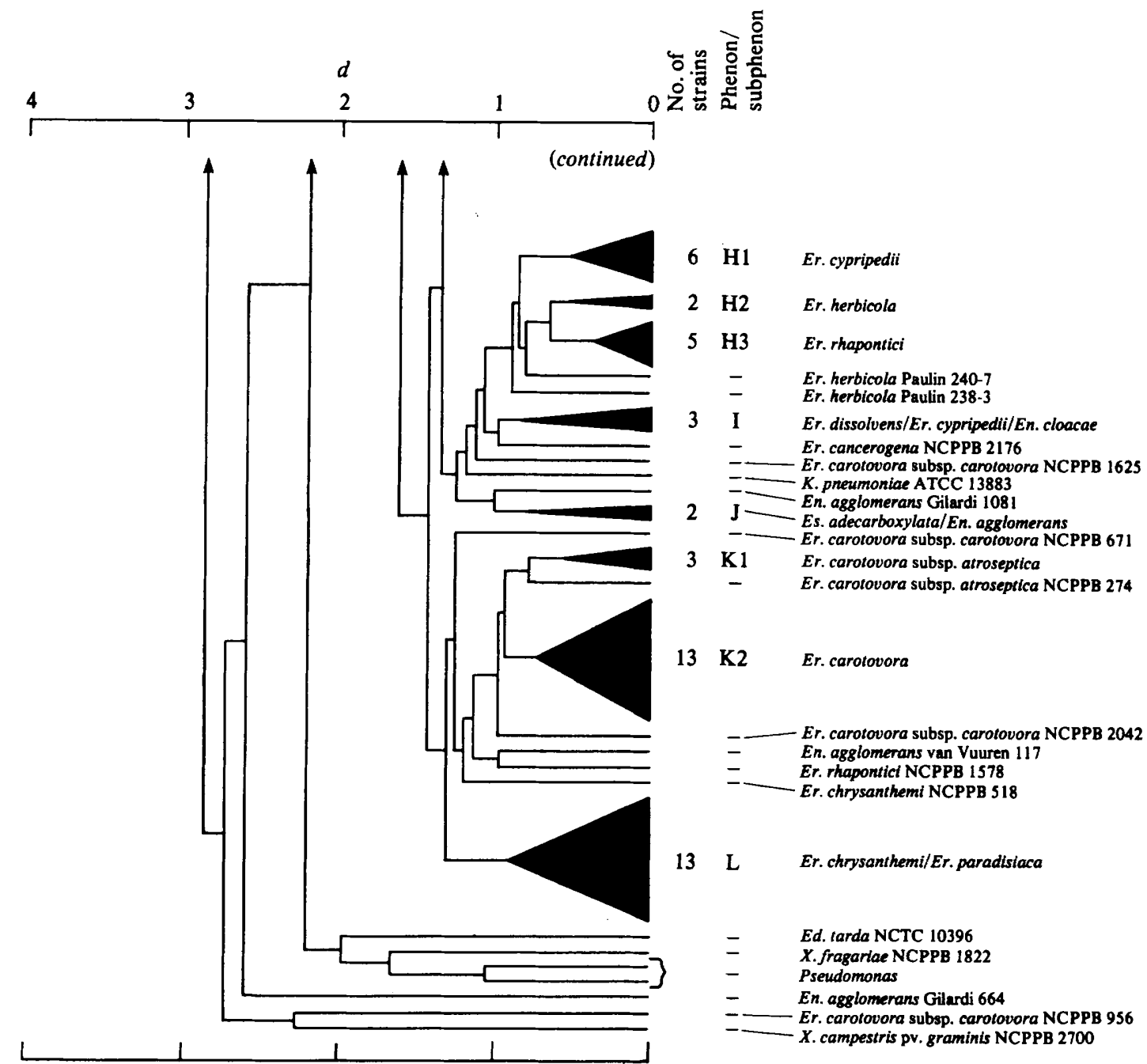

Fig. 1 (continued)

confirms earlier findings (Murata \& Starr, 1974; Sakazaki et al., 1976; Brenner, 1981; Gavini et al., 1983; Mergaert et al., 1983a; Brenner et al., 1984). The type strains of Er. herbicola (NCPPB 2971) and En. agglomerans (NCTC 9381) and all five Er. milletiae strains investigated, including the type strain NCPPB 2519, were recovered together in subphenon F2. A partial overlap of Er. herbicola, Er. milletiae and En. agglomerans has been demonstrated by Murata \& Starr (1974), Gavini et al. (1983) and Mergaert et al. (1983b). In the API 20E Analytical Profile Index, Er. herbicola has been named En. agglomerans and hundreds of different seven-digit profile numbers are used for this organism. Definite conclusions concerning the subdivisions within the 'Er. herbicola-En. agglomerans complex', and their relationships to other Enterobacteriaceae are not yet possible but certainly a taxonomic problem arises when the type strains of En. agglomerans (NCTC 9381), Er. herbicola (NCPPB 2971) and Er. milletiae (NCPPB 2519) fall within the same subphenon F2. The high phenotypic and protein electrophoretic similarities of these type strains have already been stressed by Mergaert et al. $(1983 b)$ and in this study it was impossible to differentiate them from each other by the API systems used. This is further evidence for the synonymy of the three taxa as already proposed by Ewing \& Fife (1972) and Lelliott (1974). As the phenotypic features of subphenon F2 fit Er. 


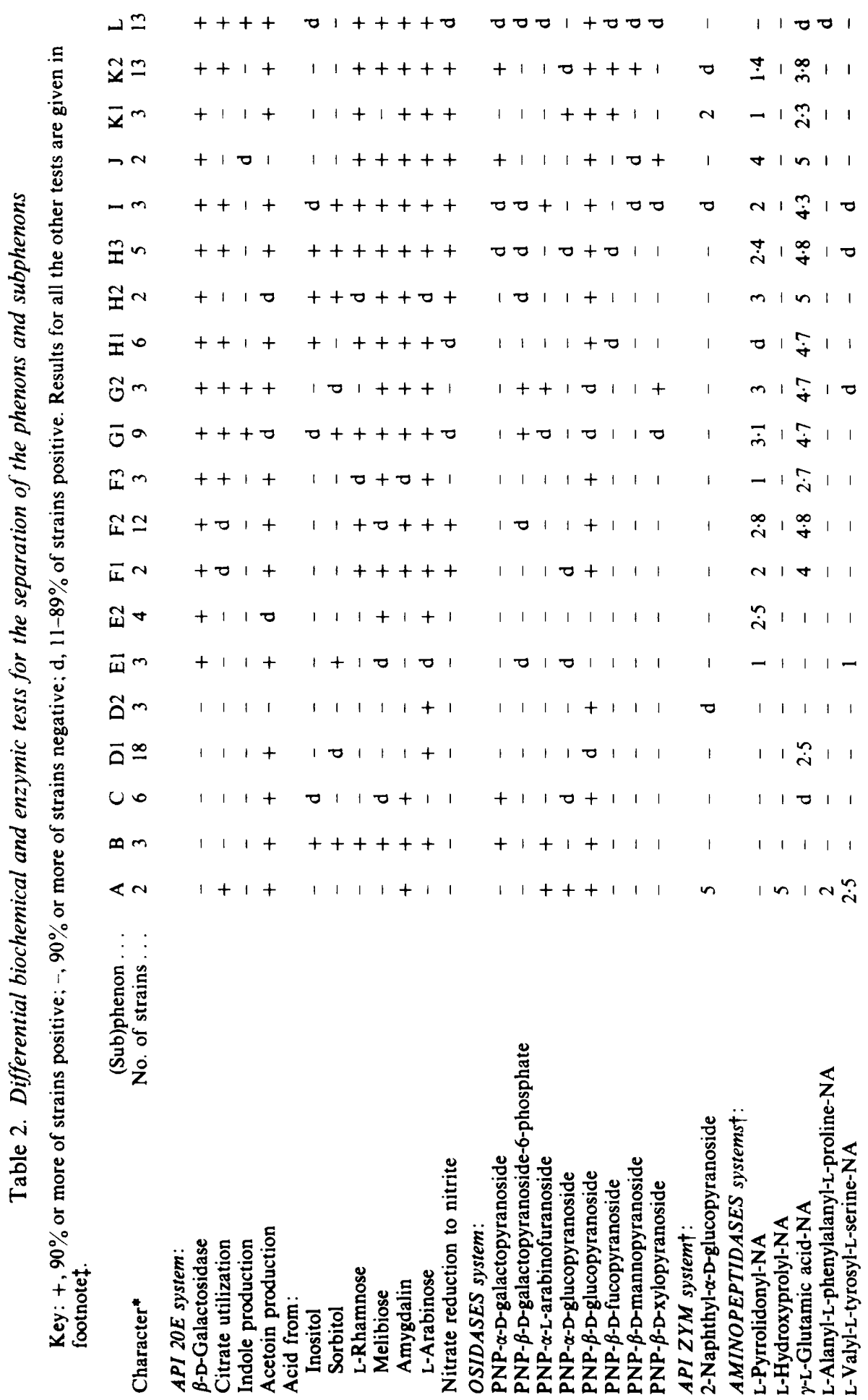




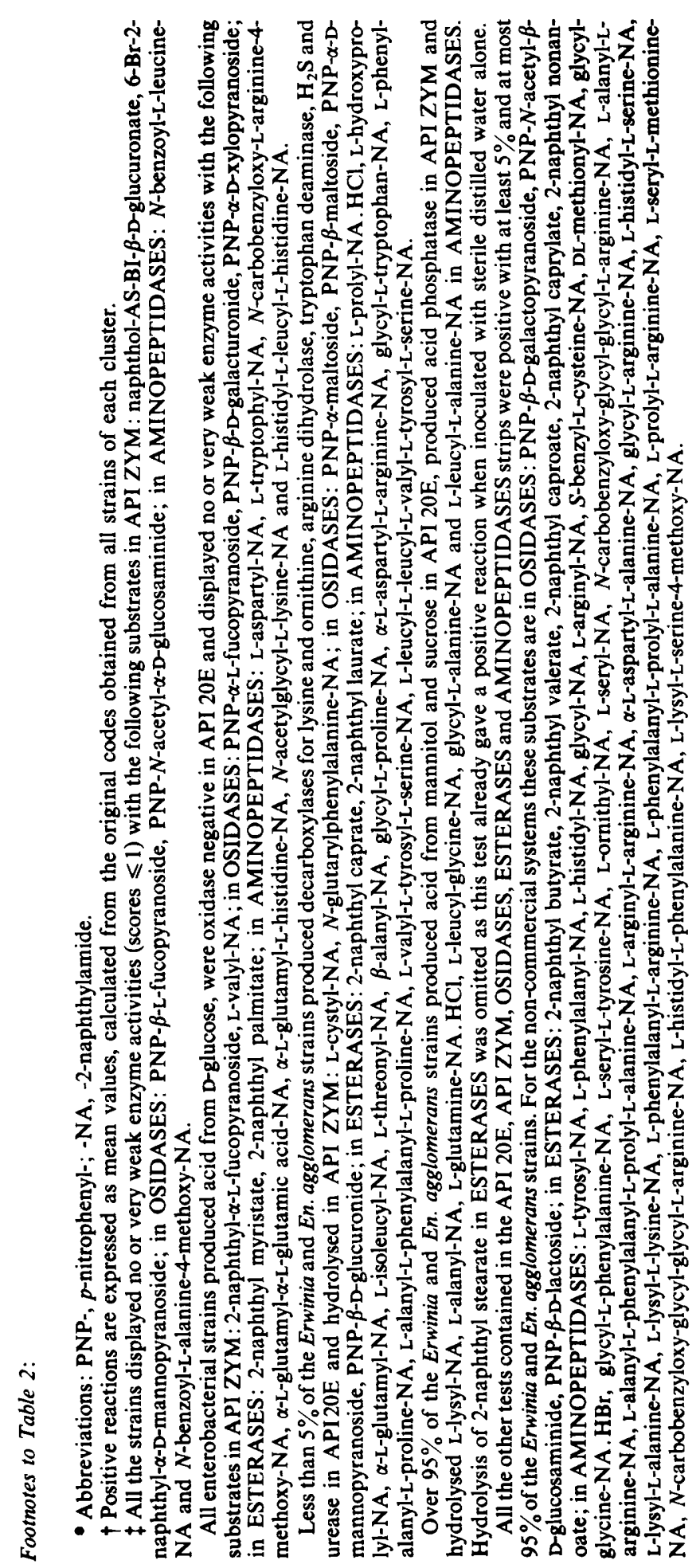


Table 3. Differential tests from the API SOCHE system for the separation of the phenons and subphenons $F 1, F 2, F 3, G 1, G 2, H 1, H 2, H 3, I, J, K 1, K 2$ and $L$

Key:,$+ 90 \%$ or more of strains positive within $6 \mathrm{~h} ;(+) 90 \%$ or more of strains positive within $48 \mathrm{~h}$; ,$- 90 \%$ or more of strains negative after $48 \mathrm{~h} ; \mathrm{d}, 11-89 \%$ of strains positive within $48 \mathrm{~h}$.

\begin{tabular}{|c|c|c|c|c|c|c|c|c|c|c|c|c|c|}
\hline $\begin{array}{l}\text { (Sub)phenon } \\
\text { No. of strains }\end{array}$ & $\begin{array}{c}\mathrm{F} 1 \\
2\end{array}$ & $\begin{array}{l}\text { F2 } \\
12\end{array}$ & $\begin{array}{c}\text { F3 } \\
3\end{array}$ & $\begin{array}{c}\text { G1 } \\
9\end{array}$ & $\begin{array}{c}\mathrm{G} 2 \\
3\end{array}$ & $\begin{array}{c}\mathrm{H} 1 \\
6\end{array}$ & $\begin{array}{c}\mathrm{H} 2 \\
2\end{array}$ & $\begin{array}{c}\mathrm{H} 3 \\
5\end{array}$ & $\begin{array}{l}\text { I } \\
3\end{array}$ & $\begin{array}{l}\mathrm{J} \\
2\end{array}$ & $\underset{3}{\mathrm{~K} 1}$ & $\begin{array}{c}\mathbf{K} 2 \\
13\end{array}$ & $\begin{array}{l}\mathrm{L} \\
13\end{array}$ \\
\hline \multicolumn{14}{|l|}{ Acid from: } \\
\hline L-Rhamnose & $(+)$ & $(+)$ & $(+)$ & $(+)$ & - & $(+)$ & $(+)$ & $(+)$ & + & $(+)$ & $(+)$ & $(+)$ & $(+)$ \\
\hline$\alpha$-Methylmannoside & - & - & - & $(+)$ & d & - & - & - & - & - & - & - & - \\
\hline$\alpha$-Methylglucoside & - & - & - & - & - & - & - & - & $(+)$ & - & $(+)$ & $\mathrm{d}$ & - \\
\hline Aesculin & + & $(+)$ & d & d & d & $(t)$ & $(+)$ & + & $\mathrm{d}$ & + & + & + & + \\
\hline D-Cellobiose & $(+)$ & - & d & $(+)$ & $(+)$ & $(+)$ & - & $(+)$ & + & + & $\mathrm{d}$ & $(+)$ & $(+)$ \\
\hline D-Maltose & $(+)$ & $(+)$ & d & $(+)$ & $(+)$ & d & $(+)$ & $(+)$ & + & + & d & - & - \\
\hline Lactose & $(+)$ & d & $(+)$ & $(+)$ & $(+)$ & - & - & d & $(+)$ & $(+)$ & d & $(+)$ & $\mathrm{d}$ \\
\hline Melibiose & $(+)$ & d & $(+)$ & $(+)$ & $(+)$ & d & - & $(+)$ & $\mathrm{d}$ & + & - & $(+)$ & d \\
\hline Sucrose & + & + & $\mathrm{d}$ & $(+)$ & + & + & - & + & + & $(+)$ & + & $(+)$ & + \\
\hline Inulin & - & - & - & - & - & - & - & - & - & - & $(+)$ & - & - \\
\hline Raffinose & - & - & d & $(+)$ & $(+)$ & - & - & $(+)$ & $\mathrm{d}$ & d & d & $(+)$ & $d$ \\
\hline D-Arabitol & $(+)$ & d & d & $(+)$ & $(+)$ & - & $(+)$ & - & - & + & - & - & _- \\
\hline
\end{tabular}

herbicola (Lelliott, 1974) as well as En. agglomerans (Ewing \& Fife, 1972) it is not clear which name should be retained for the strains of this subphenon. Different views concerning this subject have been developed by Dye (1964) and Ewing \& Fife (1972), but the situation is still more obscured by the fact that within the 'Er. herbicola-En. agglomerans complex' over 10 DNA homology groups (Brenner et al., 1984), 14 phenons (Gavini et al., 1983), 21 phenons (Murata \& Starr, 1974) and 25 protein electrophoretic groups (Mergaert et al., 1983a) have been revealed.

Erwina uredovora and Er. ananas clustered together in phenon G. Their close relationship was also revealed by Dye (1981) and Brenner $e$ t al. (1984), and both Young et al. (1978) and Dye (1981) proposed to unite them as separate pathovars in Er. ananas Serrano 1928, as Er. ananas pv. ananas and Er. ananas pv. uredovora. The probable synonymy of these two taxa is supported here as no differential features between Er. ananas and Er. uredovora were highlighted with the API systems. However, phenon $G$ was slightly heterogeneous, comprising two subphenons $G 1$ and $\mathrm{G} 2$ which could only be differentiated by acid production from L-rhamnose.

Six of the seven Er. cypripedii strains, including the type strain NCPPB 3004, constituted the homogeneous subphenon H1. Erwinia cypripedii NCPPB 2636 was a member of phenon I (see below). In each of Dye's (1981) numerical analyses, Er. cypripedii formed a well-delineated cluster. Erwinia cypripedii should be regarded as a species separate from other species of Erwinia. The API 20E seven-digit profile numbers were specific for this species, although they were identified as En. agglomerans, Klebsiella ozaenae or possible Erwinia species in the API 20E Analytical Profile Index.

Five strains labelled Er. rhapontici, isolated from Triticum aestivum, clustered in subphenon H3, whereas the type strain NCPPB 1578, which had been isolated from Rheum rhaponticum, was ungrouped. From Dye's (1981) dendrograms, it was apparent that the type strain NCPPB 1578 of Er. rhapontici is very similar to three other Rheum isolates of this species. From the present results it is questionable whether the Triticum isolates belong to the species $E r$. rhapontici. They were assigned to Klebsiella pneumoniae in the API 20E Analytical Profile Index, while the type strain of Er. rhapontici (NCPPB 1578) was assigned to En. agglomerans or possible Erwinia sp. In the API systems, the type strain differed in 15 out of 179 features from the Triticum isolates. Our data do not support Roberts' (1974) view that Triticum isolates are identical or very similar to Rheum isolates.

The type strains Er. dissolvens NCPPB 1850 and En. cloacae NCTC 10005 clustered in phenon I, together with strain NCPPB 2636, an apparently misnamed Er. cypripedii strain, although this strain was credited to be pathogenic in the NCPPB catalogue (Anonymous, 1977). Brenner et al. (1973) asserted that Er. dissolvens is more closely related to En. cloacae than to any Erwinia species. 
Enterobacter agglomerans strain ICPB 3423 and the type strain Leclerc 1783 (= ATCC 23216) of Escherichia adecarboxylata formed phenon J. This agrees with the findings of Gavini et al. (1983) and conflicts with Ewing \& Fife's (1972) proposal to incorporate Es. adecarboxylata in En. agglomerans.

Subphenon K2 contained strains labelled Er. carotovora subsp. carotovora and subsp. atroseptica together with their type strains, NCPPB 312 and NCPPB 549, respectively. These two subspecies could not be differentiated from each other by means of API systems. Others have also pointed to the high relatedness between Er. carotovora subsp. carotovora and subsp. atroseptica (Dye 1969a, 1981; Brenner et al., 1973; Murata \& Starr, 1974). We recommend that the use of both subspecies carotovora and atroseptica be discontinued. The three strains UCPPB 188, UCPPB 193 and NCPPB 2792 isolated from sugarbeets and labelled $E r$. carotovora subsp. atroseptica formed the separate subphenon K1. For these strains the name $E r$. carotovora subsp. betavasculorum has been proposed and UCPPB $193(=$ NCPPB 2795) was designated as type strain (Thomson et al., 1981). We adopt the view of Thomson et al. (1981) that the sugarbeet isolates should constitute a separate taxon.

Phenon L contained 12 Er. chrysanthemi strains, including the type strain NCPPB 402. Er. chrysanthemi has also been recognized as a separate taxon by DNA:DNA hybridization (Murata \& Starr, 1974) and numerical taxonomy (Dye, 1981). The type strain of Er.paradisiaca, NCPPB 2511, was also included in phenon L, confirming the findings of Dickey \& Victoria (1980).

Our numerical analyses give further support for the retention of the following species as separate taxa: Er. quercina, Er. nigrifluens, Er. salicis, Er. amylovora, Er. rubrifaciens, Er. mallotivora, Er. stewartii, Er. cypripedii and Er. chrysanthemi. On the other hand the results support the synonymy of the following pairs of taxa: Er. ananas and Er. uredovora, Er. dissolvens and En. cloacae, Er. carotovora subsp. atroseptica and Er. carotovora subsp. carotovora, Er. milletiae and one of the Er. herbicola clusters (subphenon F2). The heterogeneity of the 'Er. herbicola-En. agglomerans complex' is confirmed.

\section{Applicability of API systems for the classification and identification of Erwinia strains}

The API systems constitute a fast alternative to conventional phenotypical testing procedures in classificatory surveys. The API 20E and API 50CHE systems were found to have the highest discriminatory potential and reproducibility within Erwinia. In the API 20E Analytical Profile Index, strains labelled Er. cypripedii, Er. stewartii, Er. rhapontici, Er. herbicola, Er. milletiae, Er. uredovora, Er. ananas, Er. chrysanthemi, Er. carotovora and Es. adecarboxylata were assigned on the basis of their API 20E seven-digit profile numbers to En. agglomerans or possible Erwinia species, thus reflecting the inadequacy of the present classification of the 'Er. herbicola-En. agglomerans complex'. Other strains labelled Er. ananas, Er. carotovora, Er. herbicola, Er. rhapontici or Er. uredovora were assigned in the API 20E Analytical Profile Index to Klebsiella species or Serratia species. The seven-digit profile numbers of Er. amylovora, Er. quercina, Er. nigrifluens, Er. salicis, Er. rubrifaciens, Er. mallotivora and Er. tracheiphila are specific but were not listed in the API 20E Analytical Profile Index, which is mainly based on data obtained from clinical enterobacteria. They also remained unidentified after consultation of the API computer service. From the enzymic API systems, the 'OSIDASES' appeared to be the most promising for identification. Of the 58 substrates contained in the AMINOPEPTIDASES systems, 5 proved to be useful within Erwinia (see Table 2). Both the API ZYM and ESTERASES systems seemed to be of negligible discriminatory value within Erwinia. In general, our data agree well with those obtained by Godsey et al. (1981) and support the discriminative value of the following substrates for Enterobacteriaceae: L-prolyl-2-naphthylamide, L-hydroxyprolyl-2-naphthylamide, L-pyrrolidonyl-2-naphthylamide, $p$-nitrophenyl- $\beta$-D-xylopyranoside, $p$-nitrophenyl- $\beta$-D-glucopyranoside and $p$-nitrophenyl- $\alpha$-L-arabinofuranoside.

J.D.L. is indebted to the Instituut tot Aanmoediging van het Wetenschappelijk Onderzoek in Nijverheid en Landbouw (IWONL, Belgium) and the Fonds voor Kollektief Fundamenteel Onderzoek (FKFO, Belgium) for research and personnel grants. J.M. and L.V. are indebted to the IWONL for scholarships, and J.S. and K.K. to the Nationaal Fonds voor Wetenschappelijk Onderzoek (NFWO, Belgium) for equipment grants. 


\section{REFERENCES}

Aldridge, K. E., Gardner, B. B., Clark, S. S. \& MAtsen, J. M. (1978). Comparison of Micro-ID, API $20 \mathrm{E}$, and conventional media systems in identification of Enterobacteriaceae. Journal of Clinical Microbiology 7, 507-513.

ANONYMOUS (1977). Catalogue of Cultures in the National Collection of Plant Pathogenic Bacteria, 1st edn. Harpenden: Ministry of Agriculture, Fisheries and Food.

AZAD, H. R. \& KADO, C. 1. (1980). Numerical and DNA : DNA reassociation analyses of Erwinia rubrifaciens and other members of the Enterobacteriaceae. Journal of General Microbiology 120, 117-129.

Blackall, P. J. (1980). Evaluation of a multi-test microtube system for the identification of veterinary isolates of Enterobacteriaceae. Veterinary Microbiology 5, 229-237.

Blazevic, D. J., Trombley, C. M. \& Lund, M. E. (1976). Inoculation of API-20E from positive blood cultures. Journal of Clinical Microbiology 4, 522-523.

BRENNER, D. J. (1981). The genus Enterobacter. In The Procaryotes, vol. II, pp. 1173-1180. Edited by M. P. Starr, H. Stolp, H. G. Trüper, A. Balows \& H. G. Schlegel. Berlin, Heidelberg \& New York: SpringerVerlag.

BrenNer, D. J., Fanning, G. R. \& Steigerwalt, A. G. (1972). Deoxyribonucleic acid relatedness among species of Erwinia and between Erwinia species and other enterobacteria. Journal of Bacteriology 110, 12-17.

Brenner, D. J., Steigerwalt, A. G., Miklos, G. V. \& FANNING, G. R. (1973). Deoxyribonucleic acid relatedness among erwiniae and other Enterobacteriaceae : the soft-rot organisms (genus Pectobacterium Waldee). International Journal of Systematic Bacteriology 23, 205-216.

Brenner, D. J., Fanning, G. R. \& Steigerwalt, A. G. (1974). Deoxyribonucleic acid relatedness among erwiniae and other Enterobacteriaceae: the gall, wilt, and dry-necrosis organisms (genus Erwinia Winslow et al, sensu stricto). International Journal of Systematic Bacteriology 24, 197-204.

BrenNer, D. J., FanNing, G. R., LeEte KNUTSON, J. K., Steigerwalt, A. G. \& Krichevsky, M. I. (1984). Attempts to classify Herbicola group Enterobacter agglomerans strains by deoxyribonucleic acid hybridization and phenotypic tests. International Journal of Systematic Bacteriology 34, 45-55.

Butler, D. A., Lobregat, C. M. \& Gavan, T. L. (1975). Reproducibility of the Analytab (API 20E) system. Journal of Clinical Microbiology 2, 322-326.

DE SMEDT, J. \& DE LEY, J. (1979). Identification of Ruiter's strains, isolated from browned marinated herring, as members of Erwinia herbicola. International Journal of Systematic Bacteriology 29, 183-187.

DeVenish, J. A. \& BARNum, D. A. (1980). Evaluation of API 20E system and Encise Enterotube for the identification of Enterobacteriaceae of animal origin. Canadian Journal of Comparative Medicine 44, 315-319.

De Vos, P., Kersters, K. \& DE LEY, J. (1980). Identification of the leaf nodule bacterial strain $\mathrm{PeH}_{2} 20$ as Erwinia herbicola subsp. herbicola. Zentralblatt für Bakteriologie, Mikrobiologie und Hygiene (Abteilung I, Originale C) 1, 237-242.
DiCKeY, R. S. \& Victoria, J. L. (1980). Taxonomy and emended description of strains of Erwinia isolated from Musa paradisiaca Linnaeus. International Journal of Systematic Bacteriology 30, 129-134.

DYe, D. W. (1964). The taxonomic position of Xanthomonas trifolii (Huss, 1907) James, 1955. New Zealand Journal of Science 7, 261-269.

DYE, D. W. (1968). A taxonomic study of the genus Erwinia. I. The 'amylovora' group. New Zealand Journal of Science 11, 590-607.

DYE, D. W. (1969a). A taxonomic study of the genus Erwinia. II. The 'carotovora' group. New Zealand Journal of Science 12, 81-97.

DYE, D. W. (1969b). A taxonomic study of the genus Erwinia. III. The 'herbicola' group. New Zealand Journal of Science 12, 223-236.

DYE, D. W. (1969c). A taxonomic study of the genus Erwinia. IV. 'Atypical' erwinias. New Zealand Journal of Science 12, 833-839.

DYE, D. W. (1981). A numerical taxonomic study of the genus Erwinia. New Zealand Journal of Agricultural Research 24, 223-229.

EWING, W. H. \& FIFE, M. A. (1972). Enterobacter agglomerans (Beijerinck) comb. nov. (the herbicolalathyri bacteria). International Journal of Systematic Bacteriology 22, 4-11.

FranK, S. K. \& Gerber, J. D. (1981). Hydrolytic enzymes of Moraxella bovis. Journal of Clinical Microbiology 13, 269-271.

Freeman, J. W., Rowland, R. W., Overman, S. B. \& GoOdman, N. L. (1981). Laboratory evaluation of the AutoMicrobic system for identification of Enterobacteriaceae. Journal of Clinical Microbiology 13, 895-898.

Gardner, J. M. \& Kado, C. I. (1972). Comparative base sequence homologies of the deoxyribonucleic acids of Erwinia species and other Enterobacteriaceae. International Journal of Systematic Bacteriology 22, 201-209.

GAUTHIER, M. J. (1976). Alteromonas rubra sp. nov., a new marine antibiotic-producing bacterium. International Journal of Systematic Bacteriology 26, 459466.

Gavini, F., LefebVre, B. \& Leclerc, H. (1983). Étude taxonomique de souches appartenant ou apparentées au genre Erwinia, groupe herbicola, et à l'espèce Enterobacter agglomerans. Systematic and Applied Microbiology 4, 218-235.

Godsey, J. M., Matteo, M. R., Shen, D., Tolman, G. \& GoHLKE, J. R. (1981). Rapid identification of Enterobacteriaceae with microbial enzyme activity profiles. Journal of Clinical Microbiology 13, 483-490.

Goto, M. (1976). Erwinia mallotivora sp. nov., the causal organism of bacterial leaf spot of Mallotus japonicus Muell. Arg. International Journal of Systematic Bacteriology 26, 467-473.

Guillermet, F. (1980). ' Fusobacterium fusiforme' et ' $F$. nucleatum'. Annales de microbiologie 131, 95-96.

HaAhtela, K., Wartiovaara, T., Sundman, V. \& Skujins, J. (1981). Root-associated $\mathrm{N}_{2}$ fixation (acetylene reduction) by Enterobacteriaceae and Azospirillum strains in cold-climate spodosols. Applied and Environmental Microbiology 41, 203-206.

Holmes, B., Willcox, W. R., Lapage, S. P. \& MALNICK, H. (1977). Test reproducibility of the API 
(20E), Enterotube and Pathotec systems. Journal of Clinical Pathology 30, 381-387.

Holmes, B., Willcox, W. R. \& Lapage, S. P. (1978). Identification of Enterobacteriaceae by the API 20E system. Journal of Clinical Pathology 31, 2230.

Holmes, B., OWen, R. J. \& Weaver, R. E. (1981). Flavobacterium multivorum, a new species isolated from human clinical specimens and previously known as group IIk, biotype 2. International Journal of Systematic Bacteriology 31, 21-34.

Holmes, B., Owen, R. J. \& Hollis, D. G. (1982). Flavobaterium spiritivorum, a new species isolated from human clinical specimens. International Journal of Systematic Bacteriology 32, 157-165.

Humble, M. W., King, A. \& Phillips, I. (1977). API ZYM: a simple rapid system for the detection of bacterial enzymes. Journal of Clinical Pathology 30, 275-277.

ImBS, M. A. (1974). Contribution à l'étude de la taxonomie des bactéries du genre Erwinia. $\mathrm{PhD}$ thesis, Nancy, France.

Ingledew, W. M., Sivaswamy, G. \& Burton, J. D. (1980). The API 20E microtube system for rapid identification of Gram negative brewery bacteria. Journal of the Institute of Brewing 86, 165-168.

KILIAN, M. (1978). Rapid identification of Actinomycetaceae and related bacteria. Journal of Clinical Microbiology 8, 127-133.

Lelliott, R. A. (1974). Genus XII. Erwinia. In Bergey's Manual of Determinative Bacteriology, 8th edn., pp. 332-340. Edited by R. E. Buchanan \& N. E. Gibbons. Baltimore: Williams \& Wilkins.

LELliotT, R. A. \& DickeY, R. S. (1984). Genus VII. Erwinia. In Bergey's Manual of Systematic Bacteriology, pp. 469-476. Edited by N. R. Krieg. Baltimore: Williams \& Wilkins.

LJUNGH, Ȧ., POPOFF, M. \& Wadström, T. (1977). Aeromonas hydrophila in acute diarrheal disease: detection of enterotoxin and biotyping of strains. Journal of Clinical Microbiology 6, 96-100.

logan, N. A., Capel, B. J., Melling, J. \& Berkeley, R. C. W. (1979). Distinction between emetic and other strains of Bacillus cereus using the API system and numerical methods. FEMS Microbiology Letters 5, 373-375.

Mergaert, J., Kersters, K. \& De Ley, J. (1983a). Numerical comparison of protein electrophoregrams from strains of Enterobacter agglomerans (Erwinia herbicola) and allied species. In Gram Negative Bacteria of Medical and Public Health Importance: Taxonomy-Identification-Applications, p. 171. Edited by $H$. Leclerc. Paris: Éditions INSERM.

Mergaert, J., Gavini, F., Kersters, K., LeClerc, H. \& DE LEY, J. (1983b). Phenotypic and protein electrophoretic similarities between strains of Enterobacter agglomerans, Erwinia herbicola, and Erwinia milletiae from clinical or plant origin. Current Microbiology 8, 327-331.

MONGET, D. (1978). Mise au point d'une microméthode de détection et de mesure d'activités enzymatiques ( API ZYM). Résultats obtenus dans differents domaines d'application. PhD thesis, Lyon, France.

Murata, N. \& STARR, M. P. (1974). Intrageneric clustering and divergence of Erwinia strains from plants and man in the light of deoxyribonucleic acid segmental homology. Canadian Journal of Microbiology 20, 1545-1565.

MURRAY, P. R. (1978). Standardization of the Analytab Enteric (API 20E) system to increase accuracy and reproducibility of the test for biotype characterization of bacteria. Journal of Clinical Microbiology 8 , 46-49.

Mutimer, M. D. \& Woolcock, J. B. (1982). APIZYM for identification of Corynebacterium equi. Zentralblatt für Bakteriologie, Mikrobiologie und Hygiene (Abteilung I., Originale C) 3, 410-415.

Neilson, A. H. \& Sparell, L. (1976). Acetylene reduction (nitrogen fixation) by Enterobacteriaceae isolated from paper mill process waters. Applied and Environmental Microbiology 32, 197-205.

O'DONNEll, A. G., Norris, J. R., BERKeley, R. C. W., Claus, D., Kaneko, T., Logan, N. A. \& Nozaki, R. (1980). Characterization of Bacillus subtilis, Bacillus pumilis, Bacillus licheniformis, and Bacillus amyloliquefaciens by pyrolysis gas-liquid chromatography, deoxyribonucleic acid-deoxyribonucleic acid hybridization, biochemical tests, and API systems. International Journal of Systematic Bacteriology 30, 448-459.

ROBERTS, P. (1974). Erwinia rhapontici (Millard) Burkholder associated with pink grain of wheat. Journal of Applied Bacteriology 37, 353-358.

Rutherford, I., MoOdy, V., Gavan, T. L., Ayers, L. W. \& TAYLOR, D. L. (1977). Comparative study of three methods of identification of Enterobacteriaceae. Journal of Clinical Microbiology 5, 458-464.

Sakazaki, R., Tamura, K., Johnson, R. \& Colwell, R. R. (1976). Taxonomy of some recently described species in the family Enterobacteriaceae. International Journal of Systematic Bacteriology 26, 158-179.

Schwan, O., Nord, C. E. \& Holmberg, O. (1979). Biochemical characterization of unidentified microaerophilic cocci isolated from heifer and dry-cow mastitis. Journal of Clinical Microbiology 10, 622627.

SerRano, F. B. (1928). Bacterial fruitlet brown-rot of pineapple in the Philippines. Philippine Journal of Science 36, 271-305.

Skerman, V. B. D., McGowan, V. \& Sneath, P. H. A. (1980). Approved lists of bacterial names. International Journal of Systematic Bacteriology 30, 225-420.

SNeATH, P. H. A. \& Sokal, R. R. (1973). Numerical Taxonomy. The Principles and Practice of Numerical Classification. San Francisco: W. H. Freeman.

Stark, M. P. (1981). The genus Erwinia. In The Procaryotes, vol. II, pp. 1260-1271. Edited by M. P. Starr, H. Stolp, H. G. Trüper, A. Balows \& H. G. Schlegel. Berlin, Heidelberg \& New York: Springer Verlag.

Starr, M. P. \& Chatterjee, A. K. (1972). The genus Erwinia: enterobacteria pathogenic to plants and animals. Annual Review of Microbiology 26, 389426.

Tharagonnet, D., Sisson, P. R., Roxby, C. M., InghaM, H. R. \& Selkon, J. B. (1977). The API ZYM system in the identification of Gramnegative anaerobes. Journal of Clinical Pathology 30, 505-509.

Thomson, S. V., Hildebrand, D. C. \& Schroth, M. N. (1981). Identification and nutritional differentiation of the Erwinia sugar beet pathogen from 
members of Erwinia carotovora and Erwinia chrysanthemi. Phytopathology 71, 1037-1042.

van Vuuren, H. J. J., Kersters, K., De Ley, J., TOERIEN, D. F. \& MeISEL, R. (1978). Enterobacter agglomerans - a new bacterial contaminant isolated from lager beer breweries. Journal of the Institute of Brewing 84, 315-317.

W ALDEE, E. L. (1945). Comparative studies of some peritrichous phytopathogenic bacteria. Iowa State College Journal of Science 19, 435-484.

Westley, J. W., Anderson, P. J., Close, V. A.,
Halpern, B. \& Lederberg, E. M. (1967). Aminopeptidase profiles of various bacteria. Applied Microbiology 15, 822-825.

WISHART, D. (1978). Clustan. User Manual, 3rd edn. Program Library Unit. Edinburgh University, Edinburgh.

Young, J. M., Dye, D. W., Bradbury, J. F., Panagopoulos, C. G. \& Robbs, C. F. (1978). A proposed nomenclature and classification for plant pathogenic bacteria. New Zealand Journal of Agricultural Research 21, 153-177. 